\title{
Reduction of Steady-State Valproate Levels by Other Antiepileptic Drugs
}

\author{
*J. Chris Sackellares, $\nmid$ Susumu Sato, $¥$ F. E. Dreifuss, and \\ $\S$ J. Kiffin Penry \\ *Department of Neurology, University of Michigan, Ann Arbor, Michigan; \\ $\dagger$ Epilepsy Branch, NINCDS, Bethesda, Maryland; $\ddagger$ Department of Neurology, \\ University of Virginia Medical Center, Charlottesville, Virginia; and \$Bowman \\ Gray School of Medicine, Winston-Salem, North Carolina
}

\begin{abstract}
Summary: Steady-state plasma valproate (VPA) levels were analyzed in 37 children after 6 weeks of VPA therapy. Twenty-six patients were receiving other antiepileptic drugs in addition to VPA (experimental group). Eleven patients who received VPA alone served as controls. The mean VPA dose was not statistically different for the two groups (experimental group, $35.4 \mathrm{mg} / \mathrm{kg} /$ day, 11.6 SD; control group, $31.1 \mathrm{mg} / \mathrm{kg} /$ day, SD 6.6) The mean plasma VPA level was significantly lower for the experimental group $(63.0 \mu \mathrm{g} / \mathrm{ml}, \mathrm{SD} 21.8)$ than for the control $(99.3 \mu \mathrm{g} / \mathrm{ml})$, SD 23.3$)(p<0.01)$. VPA level:dose ratio (LDR) was also reduced in the experimental group (1.92, SD 0.75) as compared to controls $(3.26$, SD 0.65) $(p<0.01)$. Within the experimental group the VPA levels and VPA LDR were significantly reduced in patients receiving either phenytoin or phenobarbital. The data suggest that other antiepileptic drugs significantly alter the steady-state level to dose relationship for VPA.
\end{abstract}

Since valproic acid (VPA) is useful as an adjunctive drug for controlling several seizure types (Simon and Penry, 1975; Pinder et al., 1977), it is frequently administered to patients receiving other antiepileptic drugs (AEDs). Interactions between VPA and other AEDs have been reported. VPA may affect the pharmacokinetics of phenytoin (Patsalos and Lascelles, 1977; Mattson et al., 1978; Bruni et al., 1979; Cramer and Mattson, 1979), phenobarbital (Schobben et al., 1975; Gram et al, 1977; Wilder et al., 1978), and ethosuximide (Mattson and
Cramer, 1980). Other AEDs also affect the kinetics of VPA. After administering a single oral or intravenous dose of VPA to patients already receiving both phenytoin and phenobarbital, the volume of distribution is larger and the elimination rate higher than the same parameters measured in normal controls (Richens et al., 1976; Perucca et al., 1978). Vajda et al. (1978) reported a flattening of the steady-state plasma level to dose curve with higher doses of VPA, suggesting drug interactions affecting VPAlevels. Bowdle et al. (1979) reported a de-

Received December 12, 1980.

Address correspondence and reprint requests to Dr. Sackellares at B 4906, Clinical Faculty Office Building, Department of Neurology, University of Michigan Hospital, 1405 East Ann Street, Ann Arbor, Michigan 48109.

Key words: Valproic acid-Anticonvulsants-Drug interactions. 
cline in the minimum steady-state serum concentrations of VPA following 2 weeks of treatment with carbamazepine. In the present study, we found steady-state plasma VPA level:dose ratios (LDR) to be lower in children receiving other AEDs than in children receiving VPA alone.

\section{MATERIALS AND METHODS}

VPA plasma levels were analyzed in 37 children with absence seizures (ages 33/4 to $18^{11 / 12}$ years) who received VPA during a double-blind crossover study comparing VPA and ethosuximide. Twenty-six patients (experimental group) were receiving other AEDs at the time of entry into the study. In this group, VPA was given in addition to the drug or drugs taken at the time of entry. The control group consisted of 11 patients who received only VPA. The ages of the patients in the two groups were not significantly different.

VPA was begun in doses of $10-15 \mathrm{mg} /$ $\mathrm{kg} / \mathrm{day}$. Doses were administered orally at 0700,1500 , and $2300 \mathrm{hr}$ daily. During the first 2 weeks of VPA therapy, the dose was increased in $5-15 \mathrm{mg} / \mathrm{kg} /$ day increments until the maximum tolerated dose or 60 $\mathrm{mg} / \mathrm{kg} /$ day was reached. The doses of the concurrent AEDs were kept constant unless side effects attributable to alterations in the plasma levels of these drugs occurred. In these cases, the dose of the responsible drug was adjusted to return the plasma level of that drug to the pre-entry level. No drug changes were made after 4 weeks of VPA therapy. Neither the physician nor the pa- tients knew that the active drug was VPA, and the physician was unaware of the VPA level during the course of the study.

For purposes of the present study, drug levels obtained after 6 weeks of VPA therapy were analyzed. Blood samples were obtained at $0655 \mathrm{hr}$, prior to the $0700 \mathrm{hr}$ dose. Drug levels were assayed by gasliquid chromatography (Kupferberg, 1978).

\section{RESULTS}

The mean plasma VPA level and LDRs were significantly lower in the experimental group than in the control group. The mean VPA dosages and body weights were not significantly different (Table 1). Figure 1 shows the relationship between VPA plasma level and VPA dose for both groups. This relationship was more nearly linear for the control group than for the experimental group, and the slope of the linear regression line was steeper (2.29) for the control group than for the experimental group $(0.40)$.

To assess the role of individual drugs affecting VPA plasma levels, the patients in the experimental group were further divided according to treatment. For the six patients who received phenobarbital and VPA, the LDR of VPA $(1.80 \pm 0.68$, mean $\pm \mathrm{SD})$ was significantly less than those of patients in the control group $(p<0.01)$. There was no correlation between the phenobarbital level and the LDR for VPA. For the three patients who received phenytoin in addition to VPA, the LDR for VPA $(1.35 \pm 0.34)$ was lower than that of the control group $(p<0.01)$. The VPA LDR was also significantly lower than those of

TABLE 1. Comparison of steady-state plasma to dose relationships between experimental and control groups

\begin{tabular}{lccc}
\hline \multicolumn{1}{c}{ Variable } & $\begin{array}{c}\text { Experimental } \\
(n=26)\end{array}$ & $\begin{array}{c}\text { Control } \\
(n=11)\end{array}$ & Significance \\
\hline VPA dose $(\mathrm{mg} / \mathrm{kg} / \mathrm{day})$ & $35.4 \pm 11.6$ & $31.1 \pm 6.6$ & $\mathrm{~ns}$ \\
Body weight $(\mathrm{kg})$ & $47.6 \pm 20.6$ & $36.8 \pm 15.6$ & $\mathrm{~ns}$ \\
VPA plasma level $(\mu \mathrm{g} / \mathrm{ml})$ & $63.0 \pm 21.8$ & $99.3 \pm 23.3$ & $p<0.01$ \\
LDR $(\mu \mathrm{g} / \mathrm{ml}: \mathrm{mg} / \mathrm{kg} / \mathrm{day})$ & $1.92 \pm 0.75$ & $3.26 \pm 0.65$ & $p<0.01$ \\
\hline
\end{tabular}

Means \pm SD are presented. Abbreviations: VPA, valproic acid; LDR, plasma level:dose ratio; ns, not significant. 


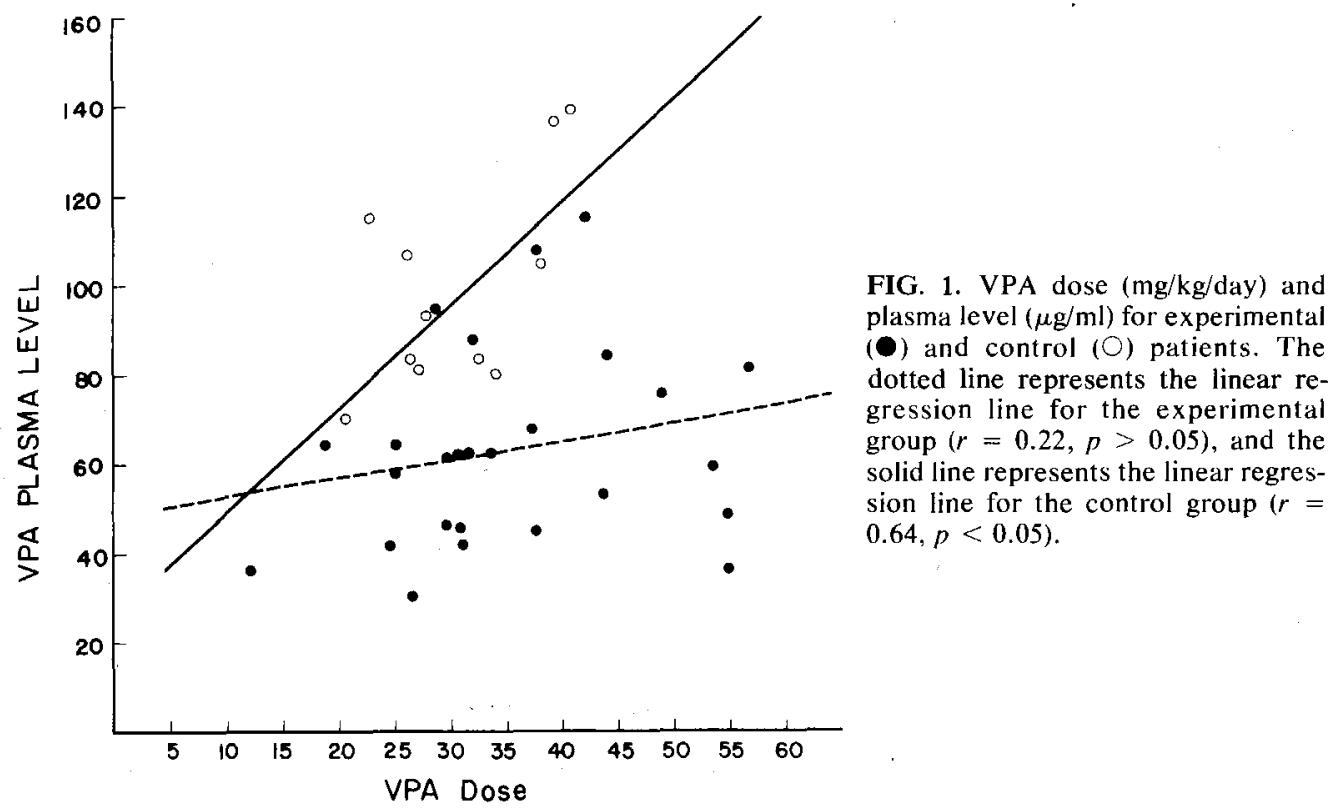

controls in the five patients who received both phenytoin and phenobarbital in addition to VPA $(2.26 \pm 0.72 ; p<0.05)$. These values were not significantly different than those of patients receiving only phenytoin or only phenobarbital in addition to VPA.

Only one patient received mephobarbital alone in addition to VPA. In this patient, the LDR for VPA was over two standard deviations less than that of the control group. For the patient who received primidone in addition to VPA, the LDR for VPA was 3.29 , very close to the mean LDR for the control group. One patient received only carbamazepine in addition to VPA. The LDR for this patient was 2.73, less than one standard deviation below that of the mean LDR for the controls. The remaining 12 patients in the experimental group received two or more drugs in addition to VPA.

\section{DISCUSSION}

The steady-state LDR of VPA was significantly lower in patients receiving phenytoin, phenobarbital, or both phenytoin and phenobarbital. The effects of phenytoin and phenobarbital were not additive. The effects of the other AED steady-state VPA plasma levels could not be determined because of the small number of patients in these groups.

There was good correlation between the daily dose and plasma level when VPA was administered as a sole therapy (control group). However, there was poor correlation betweeen the daily dose and plasma level for subjects receiving other AEDs. The slope of the level to dose curve for the experimental group is much steeper than that of the control group (Fig. 1). This suggests that when VPA is used as sole therapy, a change in the daily maintenance dose will result in much larger changes in the steady-state plasma levels than would be expected in patients also receiving phenytoin or phenobarbital.

Drug interactions of the magnitude observed in this study confound predictions of steady-state plasma levels. Therefore, close monitoring of VPA plasma levels is required until steady state is achieved. VPA LDRs may also change following dosage changes or discontinuation of other AEDs and the time to reach new steady-state VPA levels is not known. 
The maximum tolerated doses were similar for subjects receiving other AEDs and those receiving VPA alone, even though the plasma levels were significantly lower in those receiving other drugs. This suggests that there was synergistic toxicity or that the dose-limiting side effects (drowsiness or nausea) were due to high free-fractions of VPA or phenytoin, or higher concentration of active metabolites of VPA as a result of hepatic enzyme-induction. The presence of phenytoin, at least in high concentrations, increases the plasma free-fraction of VPA (Cramer and Mattson, 1979; Monks et al., 1978). The magnitude of this effect at steady state is not known, but probably varies with the concentration of both drugs. Since VPA is highly protein bound (Klotz and Antonin, 1977; Gugler and Mueller, 1978; Cramer and Mattson, 1979), small increases in the free fraction of VPA could result in significant changes in both toxic and therapeutic effects. Therefore, the lower total VPA levels in patients who were receiving phenytoin may not accurately reflect the biological activity of VPA. Measurement of the free fraction as well as total VPA levels may more accurately reflect the biological activity, particularly when VPA is used in combination with phenytoin.

Since the elimination of VPA from plasma is of the flow-independent restrictive type, only the unbound drug can be cleared (Klotz and Antonin, 1977). Therefore, an increase in the free fraction of VPA could have contributed to the lower steady-state VPA concentrations observed in patients receiving phenytoin. Any drug which competes with VPA for plasma protein binding sites would be expected to have a similar effect. Phenobarbital is approximately $40 \%$ bound to plasma protein, (Waddell and Butler, 1957), and there is no evidence that phenobarbital competes with VPA for plasma protein binding sites. Neither phenytoin or phenobarbital affects gastrointestinal absorption of VPA (Perucca et al., 1978). Therefore, it is likely that phenobarbital lowers steady-state VPA levels by induction of hepatic enzymes, as suggested by Gugler and Unruh (1980). If this be the case, the biological effects of VPA, for a given steady-state plasma VPA concentration, would depend on whether or not the metabolites of VPA are biologically active.

\section{ACKNOWLEDGMENT}

This study was supported by NIH Contract No. 1-9-2196. We wish to thank Dr. Harvey Kupferberg, who performed the plasma anticonvulsant level assays, and to Ms. Deanna Kirby for technical assistance.

\section{REFERENCES}

Bowdle TA, Levy RH, and Cutler RE. Effects of carbamezapine on valproic acid kinetics in normal subjects. Clin Pharmacol Ther 26:629-634, 1979.

Bruni J, Wilder BJ, Wilmore LJ, et al. Valproic acid and plasma levels of phenytoin. Neurology 29:601, 1979.

Cramer JA and Mattson RH. Valproic acid: In vitro plasma protein binding and interaction with phenytoin. Ther Drug Monitor 1:105-116, 1979.

Gram L, Wulff K, Rasmussen KE, Flachs $H$, WurtzJorgensen A, Sommerbeck KW, and Lohren V. Valproate sodium: A controlled clinical trial including monitoring of drug levels. Epilepsia 18:141-148, 1977.

Gugler $R$ and Mueller G. Plasma protein binding of valproic acid in healthy subjects and in patients with renal disease. Br J Clin Pharmacol 5:441-446, 1978.

Gugler R and von Unruh GE. Clinical pharmacokinetics of valproic acid. Clin Pharmacokinet 5:67-83, 1980.

Klotz U and Antonin KH. Pharmacokinetics and bioavailability, of sodium valproate. Clin Pharmacol Ther 21:736-743, 1977.

Kupferberg HJ. Gas-liquid chromatographic quantitation of valproic acid. In: Pippinger CE, Penry JK, and Kutt H (Eds), Antiepileptic Drugs: Quantitative Analysis and Interpretation, Raven Press, New York, 1978, pp 147-151.

Mattson RH and Cramer JA. Valproic acid and ethosuximide interaction. Ann Neurol 7:583-584, 1980.

Mattson RH, Cramer JA, Williamson PD, and Novelly RA. Valproic acid in epilepsy: Clinical and pharmcological effects. Ann Neurol 3:20-25, 1978.

Monks A, Boobis A, Wadsworth J, and Richens A. Plasma protein binding interactions between phenytoin and valproic acid in vitro. $B r J$ Pharmacol 6:487-492, 1978.

Patsalos PN and Lascelles PT. Effect of sodium valproate on plasma protein binding of diphenylhydantoin. J Neurol Neurosurg Psychiatry 40:570$574,1977$. 
Perucca E, Gatti G, Frigo GM, Crema A, Calzetti S, and Visiniti D. Sodium valproate in epileptic patients. Br J Pharmacol 5:495-499, 1978.

Pinder RM, Brogden RN, Speight TM, and Avery GS. Sodium valproate: A review of its pharmacological properties and therapeutic efficacy in epilepsy. Drugs 13:81-123, 1977.

Richens A, Scoular IT, Ahmad S, and Jordan BJ. Pharmacokinetics and efficacy of Epilim in patients receiving long-term therapy with other antiepileptic drugs. In: Legg NJ (Ed), Clinical and Pharmacological Aspects of Sodium Valproate (Epilim) in the Treatment of Epilepsy, MCS Consultants, Tunbridge Wells, 1976, pp. 78-88.

Schobben F, van der Kleijn E, and Gabreels FMJ. Pharmacokinetics of di-n-propylacetate in epileptic patients. Eur J Clin Pharmacol 8:98-105, 1975.

Simon D and Penry JK. Sodium di-n-propylacetate (DPA) in the treatment of epilepsy; a review. Epilepsia 16:549-573, 1975.

Vajda FJE, Drummer OH, Morris PM, McNeil JJ, and Bladin PF. Gas chromatographic measurement of plasma levels of sodium valproate: Tentative therapeutic range of a new anticonvulsant in the treatment of refractory epileptics. Clin Exp Pharmacol Physiol 5:67-73, 1978 .

Waddell WJ and Butler TC. The distribution and excretion of phenobarbital. $J$ Clin Invest $36: 1217$ 1226, 1957.

Wilder BJ, Willmore LJ, Bruni J, and Villarreal HJ. Valproic acid: Interactions with other anticonvulsant drugs. Neurology 28:892-896, 1978.

\section{RÉSUMÉ}

Le taux plasmatique a l'équilibre du valproate de sodium (VPA) a été étudié chez 37 enfants après 6 semaines de therapeutique. Vingt six patients reçoivent d'autres médicaments antiépileptiques associés au VPA (groupe expérimental) alors que 11 sujets témoins ne reçoivent que le VPA seul. La posologie moyenne du VPA n'est pas significativement différente entre les deux groupes $(35,4 \mathrm{mg} / \mathrm{kg} / \mathrm{jour} \pm 11,6$ contre $31,1 \mathrm{mg} / \mathrm{kg} /$ jour $\pm 6,6$ ). Le taux plasmatique de VPA est significativement plus bas dans le groupe expérimental $(63,0 \mu \mathrm{g} / \mathrm{ml} \pm 21,8)$ contre $99,3 \mu \mathrm{g} / \mathrm{ml} \pm$ 23,3 dans le groupe témoin $(p<0,01)$. Le rapport taux plasmatique/posologie (LDR) a été diminué dans le groupe expérimental $(1,92 \pm 0,75)$ par rapport au groupe témoin $(3,26 \pm 0,65), p<0,01$ en particulier chez les malades recevant de la phénytö̈ne ou du phénobarbital. La posologie moyenne du VPA n'étant pas significativement différente dans lés deux groupes, les faits observés suggèrent que l'addition d'autres antiépileptiques est capable de modifier le taux à l'équilibre du VPA plasmatique en fonction de la dose administrée.

\section{RESUMEN}

Se analizaron los niveles estables de valproato en plasma (VPA) en 37 niños después de 6 semanas de terapia con VPA. Ventiseis pacientes recibian otros fármacos además de VPA (grupo experimental) y once sólo tomaban VPA y sirvieron como controles. La dosis media de VPA no fue significativamente distinta en los dos grupos (grupo experimental: $35,4 \mathrm{mg}$ / $\mathrm{kg} /$ día, DS 11,6; grupo control: $31.1 \mathrm{mg} / \mathrm{kg} /$ día, DS 6,6). El nivel plasmático medio de VPA fue significativamente inferior en el grupo experimental $(63,0 \mu \mathrm{g} / \mathrm{ml}$, DS 21,8$)$ que en el control $(99,3 \mu \mathrm{g} / \mathrm{ml}$, DS 23,3$), p<$ 0,01. La relación nivel de VPA: dosis (LDR) estaba también reducida en el grupo experimental $(1,92$, DS 0,75 ) al compararla con los controles $(3,26, \mathrm{DS}$ $0,65), p<0,01$. Dentro del grupo experimental los niveles de VPA y la LDR estaban significativamente reducidos en pacientes que tomaban fenitoina o fenobarbital. La dosis media no fue diferente entre los grupos experimental y control. Estos datos sugieren que la ingestión de otros fármacos alteran de modo significativo los niveles estables de VPA en relación con la dosis.

(A. Portera Sanchez, Madrid)

\section{ZUSAMMENFASSUNG}

In steady-state befindliche Plasma Valproatspiegel (VPA) wurden bei 37 Kindern nach 6 wöchiger VPATherapie analysiert. 26 Patienten erhielten zusătzlich zum VPA andere Antiepileptika (experimentelle Gruppe). 11 Patienten, die VPA alleine bekamen, dienten als Kontrollen. Die mittlere VPA-Dosis war in beiden Gruppen nicht signifikant Vunterschiedlich (experimentelle Gruppe $35,4 \mathrm{mg} / \mathrm{kg}$ pro Tag, 11,6 SD; Kontrollgruppe $31,1 \mathrm{mg} / \mathrm{kg}$ pro Tag, SD 6,6 ). Der mittlere Plasma VPA-Spiegel war signifikant niedriger in der experimentellen Gruppe $(63,0 \mu \mathrm{g} / \mathrm{ml}, \mathrm{SD} 21,8)$ als in der Kontrollgruppe $(99,3 \mu \mathrm{g} / \mathrm{ml}$, SD 23,3$), p<$ 0.01. Das Verhältnis VPA-Spiegel: Dosis (LDR) war in der experimentellen Gruppe ebenfalls reduziert $(1,92$, SD 0,75) gegenüber der Kontrollgruppe (3,26, SD 0,65), $p<0.01$. Innerhalb der experimentellen Gruppe waren die VPA-Spiègel und die VPA/LDR bei Patienten, die entweder Phenytoin oder Phenobarbital bekamen, signifikant erniedrigt. Die mittlere VPADosis war nicht signifikant unterschiedlich in der experimentellen und in der Kontrollgruppe. Diese Daten lassen vermuten, daß andere Antiepileptika signifikanterweise den: Steady-state-Spiegel im Hinblick auf die verabfolgte Dosis VPA ändern.

\section{(P. Bouyard, Marseilles)}

(D. Scheffner, Heidelberg) 